\title{
Radiation prosthetic stents applied to oral cancer patients during the radiation therapy: case reports
}

\author{
Ki Young Nam* \\ Department of Dentistry, College of Medicine, Keimyung University, Daegu, Republic of Korea
}

Radiation prosthetic stent is defined as the customized oral devices which serve for an efficient administration of radiation dose to the affected areas or a minimizing the unnecessary irradiation to surrounding normal tissues during maxillofacial cancer radiotherapy. Since the use of stents is individualized, a close collaboration among radiotherapist, surgeon and prosthodontist is essential thereby which helps in limiting the post-therapy morbidity as well as the stable oral rehabilitation. In this report, two customized stents (bolus carrier and tongue depressing) were fabricated and applied to patient undergone irradiation for soft palate and tongue carcinoma selectively. Multidisciplinary approach can be a proper strategy and recommended for control the sequel of post-irradiation. (J Dent Rehabil Appl Sci 2020;36(4):282-8)

Key words: multidisciplinary approach; oral cancer; radiation prosthetic stents; radiotherapy

\begin{abstract}
서론
구강방사선스텐트(radiation prosthetic stent)는 방사 선요법(radiation therapy) 시 종양의 영역과 인접조직 그 리고 방사선 입사 방향 및 용량 등에 대한 조사 효율 및 일관성 더불어 주위조직 차폐 등의 효과를 도모하기 위 한 보조적인 치과장치물로 적용된다. 이 구내장치물은 주로 방사선종양학과의 의뢰로 제작되며 그 목적은 방 사선조사에 따른 합병증의 예방 혹은 최소화 그리고 조 사 후 원활한 구강조직의 회복이다. ${ }^{1}$ 방사선요법은 종양 세포에 대한 관혈적 혹은 비관혈적 처치에 있어 전리방 사선을 화학요법과 결합하거나 호환하지 않는 항암치료 법으로 ${ }^{2}$ 구강암치료에서 필수적 수단으로 널리 시행되 고 있지만 치아우식, 점막괴사, 타액선 질환, 방사선 골괴 사증(osteoradionecrosis) 등의 인접 정상조직에 대한 여 러 부작용을 초래할 수 있다. ${ }^{3}$ 이러한 합병증은 종종 환
\end{abstract}

*Correspondence to: Ki Young Nam Professor, Department of Dentistry, School of Medicine, Keimyung University 1095 Dalgubeol-daero, Dalseo-gu, Daegu, 42601, Republic of Korea Tel: +82-53-258-7945, Fax: +82-53-258-4683, E-mail: nkyp@dsmc.or.kr Received: October 12, 2020/Last Revision: October 22, 2020/Accepted: October 28,2020
자들의 삶의 질, 재활의 수준, 후속 치료 과정에 대한 시 술 의지를 저하시키고 추후 구강 수복에 대한 치과전문 의의 최적 시술을 제한시킬 수 있으므로 ${ }^{4}$ 조사 시 종양 조 직에 대한 선원(radiation beam)의 표적화와 정상조직 보 호가 시술 전에 최대한 고려되어야 한다. 세기조절 방사 선치료(intensity-modulated radiotherapy, IMRT) 도입과 Palifermin, Benzydamine 등의 구강 세척제 혹은 방사선 보호 약제가 후유증조절의 수단으로 적용되나 조사효율 및 일관성 그리고 주변조직의 최소 침습화 등을 위한 환 자마다의 맞춤식 구강장치제작의뢰가 방사선치료전문의 로부터 증가되고 있다. ${ }^{1,5}$ Munshi ${ }^{6}$ 는 효율적이며 경제적 인 항암치료에 대한 관련 전문의들의 다학제 접근(multidisciplinary approach)을 중요한 전략으로 언급하였는데 두경부외과의, 방사선치료전문의는 구내장치를 이용한 치과의 지원 효과를 일차적으로 인식하고 치과전문의는 두경부암 치료진의 일원으로서 협진에 적극적인 역할을

Copyright@ 2020 The Korean Academy of Stomatognathic Function and Occlusion. (c) It is identical to Creative Commons Non-Commercial License. 
담당하여 술 후 환자의 포괄적 재활을 용이하게 할 수 있 다. 본 보고는 구강 내 편평세포암 환자의 방사선치료 시 다학제 접근으로 제작된 2종의 구강방사선스텐트인 볼 러스함입형(tissue-bolus carrier)스텐트와 설압형(tongue depressing) 마우스피스를 선택적으로 적용하여 원활한 치료경과 및 예후를 도출하였기에 증례와 함께 보고하고 자 한다.

\section{증례보고}

Table 1은 본원 방사선종양학과에서 방사선 구강장치 물의 제작을 주소로 최근 2년간(2016년 11월-2018년 10 월) 치과로 의뢰된 구강암환자들의 임상양상이며 연구개 암에는 볼러스함입형, 설암에는 설압형이 방사선종양학 과로부터 각각 요청되었다.

\section{볼러스함입형(tissue-bolus carrier) 스텐트}

59세 남성 환자 1 의 경우 연구개후방 편평세포암 (squamous cell carcinoma, $\mathrm{T}_{2} \mathrm{~N}_{0} \mathrm{M}_{0}$ ) 으로 진단되었고 (Fig. 1A) 비외과적 적출과 화학-방사선 병용치료(concurrent chemo-radiation therapy)가 계획되었으며 구강 장치의뢰의 목적은 종양표적부에 대한 효율적인 선량의 전달이었다. 다학적 토의에서 방사선스텐트는 폴리에틸 렌(polyethylene) 소재의 조직등가물질인 볼러스(Bolus, $\mathrm{BOLX}^{\mathrm{TM}}$, Klarity, USA)가 담체된 가철성 의치형태로 결 정되었고 가공선 클라스프로 유지력을 부여하였다. 예 비인상 후 표적 병변부의 최후방범위를 인기하기 위하여 연구개후방으로 과연장된 개인트레이로 주인상채득 후 (Fig. 1B) 주모형상에서 최종적인 종양 후방경계 설정과 보상체인 볼러스의 피개면적 및 두께 $(1.0 \mathrm{~cm})$ 에 대한 왁

Table 1. Characteristics of the consulted patients from radiology from November 2016 to October 2018

\begin{tabular}{ccccccc}
\hline Patient & Sex/Age & Diagnosis & Primary location & Stage* & Radiation dose & Type of stent \\
\hline 1 & $\mathrm{M} / 59$ & & & $\mathrm{~T}_{2} \mathrm{~N}_{0} \mathrm{M}_{0}$ & $70 \mathrm{~Gy} / 35 \mathrm{fr}$ & \\
2 & $\mathrm{M} / 77$ & & Soft palate & $\mathrm{T}_{2} \mathrm{~N}_{2 \mathrm{c}} \mathrm{M}_{0}$ & $70 \mathrm{~Gy} / 33 \mathrm{fr}$ & Tissue-bolus carrier \\
3 & $\mathrm{~F} / 65$ & Squamous cell & & $\mathrm{T}_{2} \mathrm{~N}_{2 \mathrm{c}} \mathrm{M}_{1}$ & $4 \mathrm{~Gy} / 2 \mathrm{fr}$ & \\
4 & $\mathrm{M} / 73$ & carcinoma & Hard/soft palate & $\mathrm{T}_{3} \mathrm{~N}_{1} \mathrm{M}_{0}$ & $70 \mathrm{~Gy} / 35 \mathrm{fr}$ & \\
5 & $\mathrm{M} / 62$ & (SCC) & Lateral tongue & $\mathrm{T}_{1} \mathrm{~N}_{1} \mathrm{M}_{0}$ & $66 \mathrm{~Gy} / 33 \mathrm{fr}$ & Tongue-depressor \\
6 & $\mathrm{M} / 75$ & & Tongue & $\mathrm{T}_{1} \mathrm{~N}_{0} \mathrm{M}_{0}$ & $60 \mathrm{~Gy} / 30 \mathrm{fr}$ & \\
\hline
\end{tabular}

* Systematic TNM classification of the American joint committee on cancer. Gy, Gray; fr, Fraction.
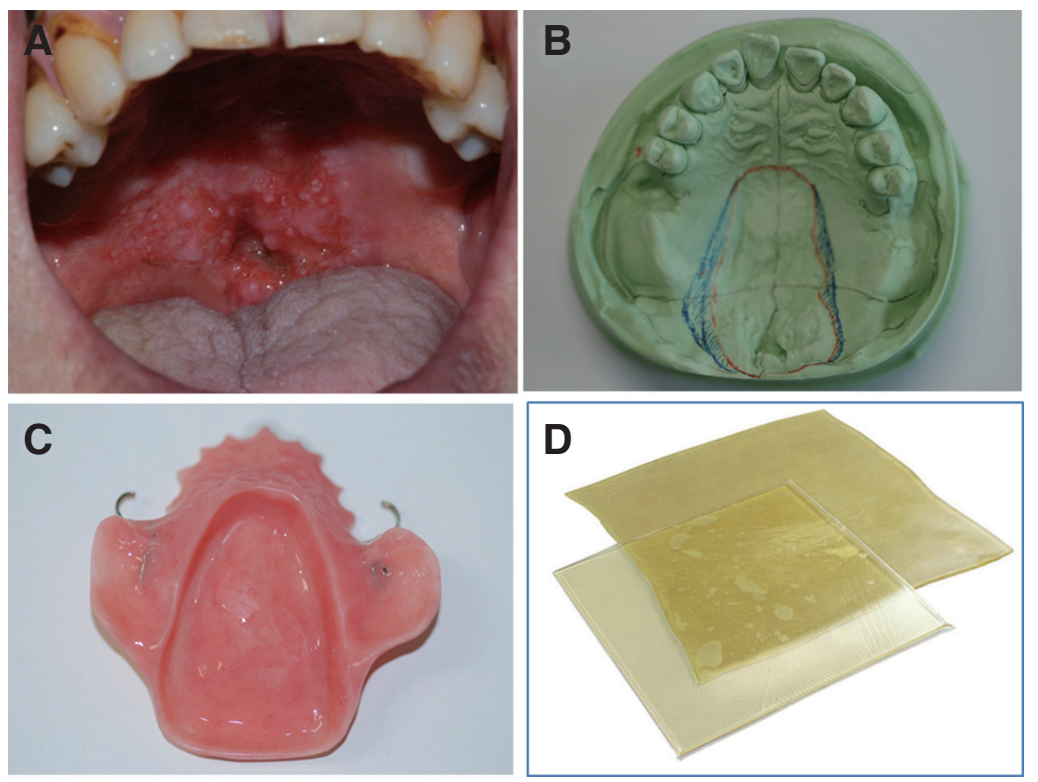

Fig. 1. Pre-radiotherapy state of soft palate SCC in patient 1 (A). Designation of wax relief for bolus deposit on master cast (B). Tissue surface of stent with hollow space for bolus (C). Commercial tissue bolus (Bolus, BOLX ${ }^{\mathrm{TM}}$, Klarity, USA) (D). 

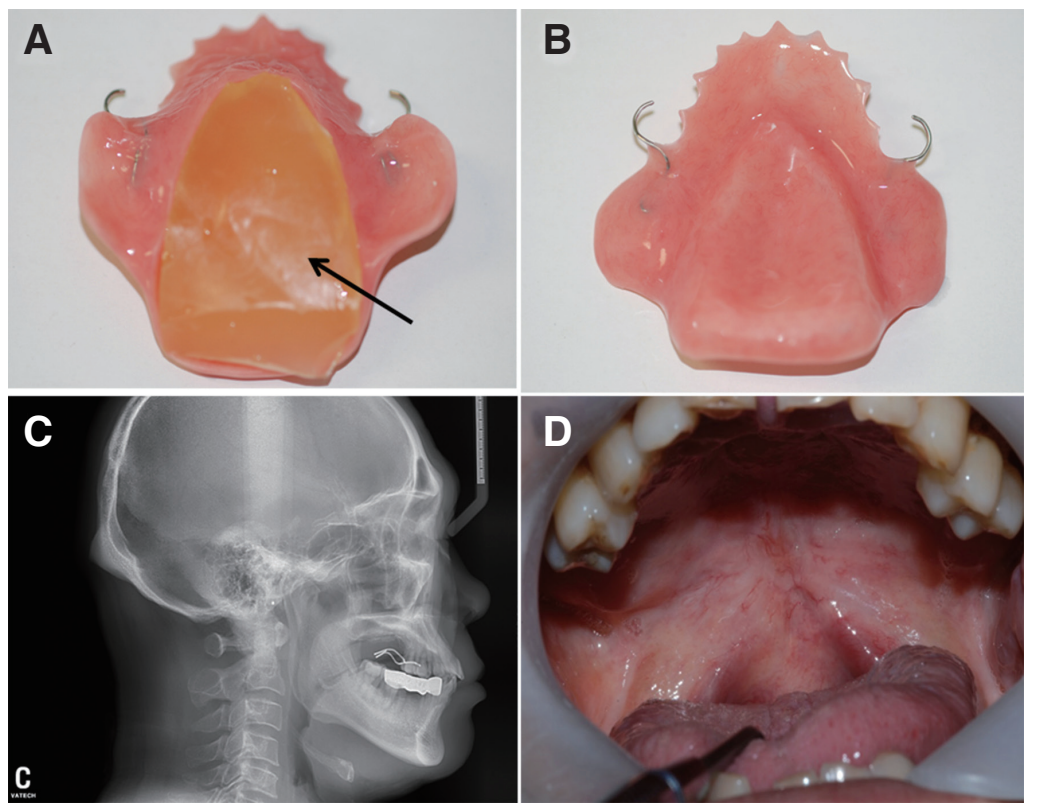

Fig. 2. Gel bolus (arrow) packed in relief space within stent for irradiated spot (A). Polished surface of stent with retentive wire clasp (B). Cephalometric view on simulation (C). Postoperative healing state after 6 months follow up (D).
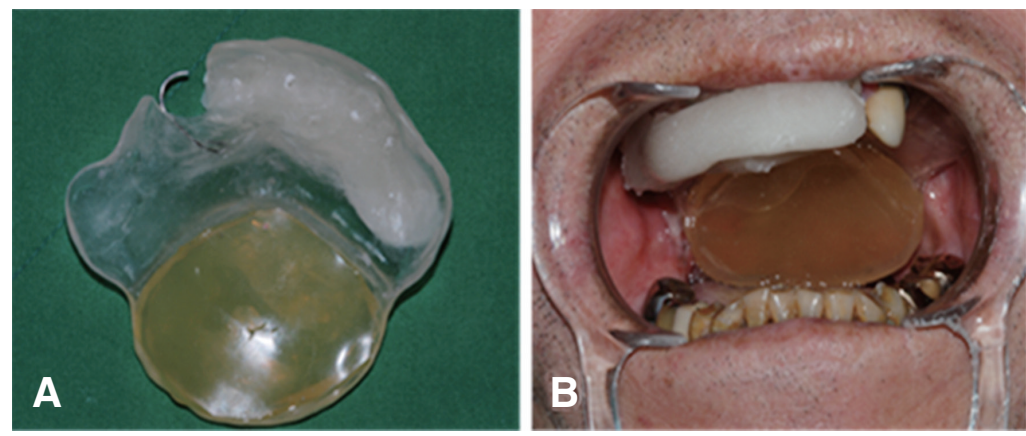

Fig. 3. Bolus-carrier of transparent $P M M A$ type in patient 4 (A). Try- in on simulation (B).
스 릴리프를 시행하였다(Fig. 1C, 1D). 장치재료는 polymethyl methacrylate (PMMA)를 선택하였고 온성 후 왁 스 릴리프로 보상된 함몰공간내에 볼러스를 담체하여 조 정 및 연마하였다(Fig. 2A, 2B). 술 전 안정된 스텐트장착 과 조사각도, 환자 적응 등을 고려한 방사선 모의치료를 시행하였다(Fig. 2C). 방사선치료 종료 6개월 후의 추적 결과에서 특이한 구강합병증이 없는 안정적인 종양 치유 가 관찰되었고(Fig. $2 \mathrm{D}$ ) 기존 상실치아에 대한 보철치료 를 진행하였다. Fig. 3 은 환자 1 과 유사한 병소를 가진 73 세 남성 환자 $4\left(\mathrm{~T}_{3} \mathrm{~N}_{1} \mathrm{M}_{0}\right)$ 에 적용된 볼러스함입형의 다른 형태이다.

\section{설압형 마우스피스(Tongue depressing mouthpiece)}

62세 남성 환자 5 의 경우 우측면 혀의 편평세포암 $\left(\mathrm{T}_{1} \mathrm{~N}_{1} \mathrm{M}_{0}\right)$ 으로 이비인후과에서 관혈적 적출이 시행되었
고(Fig. 4A) 추가 방사선치료 전 개구증대 및 혀의 위치고 정(position maintaining)을 위한 구내장치물 제작이 방 사선종양학과로부터 의뢰되었다. 다학적 토의에서 장치 물은 방사선 조사 시 혀를 압하하고 방사선 빔(beam)과 이하선(parotid gland)과의 일정한 간극을 유지하는 마우 스피스 형태로 설계되었다. 예비인상 후 상, 하악 진단모 형상에서 왁스교합제(wax rim)를 마우스피스형태로 형 성하였고(Fig. 4B) 혀를 압하하기 위한 장치 하부 풍융부 (balloon)의 크기는 의뢰과의 요구, 환자의 최대개구량 및 생리적 적응한계를 최적으로 반영하여 결정하였고 시 적 시 약 $25 \mathrm{~mm}$ 의 교합거상이 유도되었다(Fig. $4 \mathrm{C}$ ). 온 성 및 고도연마 후 완성된 장치물은 모의치료에서 시험 장착되었고 교합거상과 장치이물감에 따른 환자의 특발 적인 거부반응은 관찰되지 않았다. 환자 6 의 경우 모의장 착 중 간헐적 호흡곤란을 호소하여 풍융부 전방에 환기 구멍(ventilation holes)을 형성하였다(Fig. 5). 

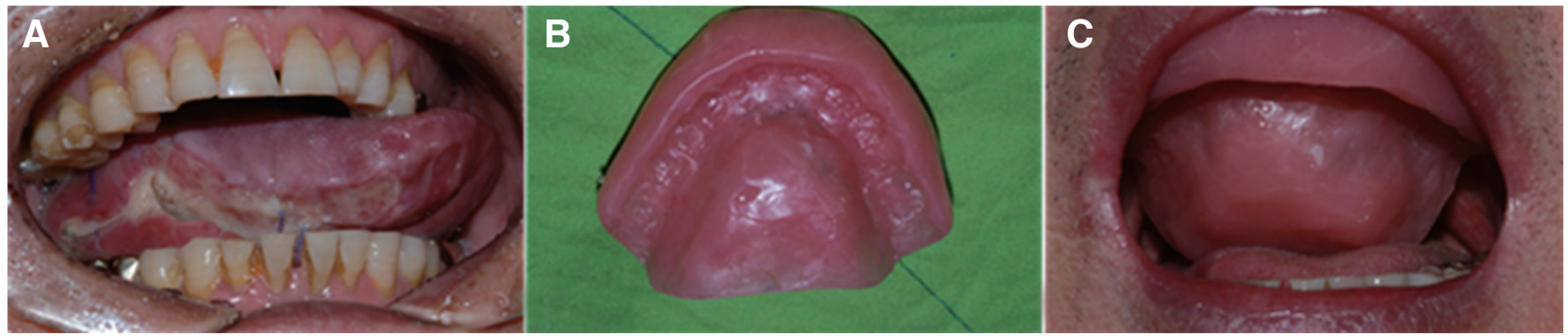

Fig. 4. Clinical aspect of patient 5 with right tongue SCC (A), Wax rim assessment for amount of ballooning and vertical dimension with radiotherapist (B), Try in state with $25 \mathrm{~mm}$ of vertical dimension increased and depressed tongue during radiation (C).

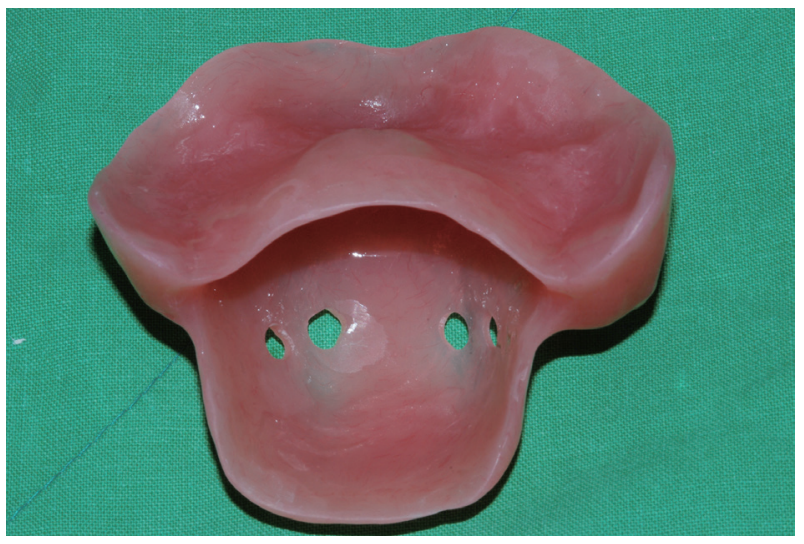

Fig. 5. Ventilation holes for airway patency in patient 6.

\section{고찰}

악안면종양처치에서 방사선치료과와 두경부외과 그 리고 치과의 포괄적이고 상호지원적인 다학제 접근은 치 료계획의 단순화와 환자의 재활에 효율적이며 초기진행 $\left(\mathrm{T}_{1} / \mathrm{T}_{2}, \mathrm{~N}_{0}\right)$ 상태인 비인두암, 혀 그리고 구강저 종양의 방사선치료에 여러 구강 스텐트 적용들이 보고되고 있 다. ${ }^{7}$ 스텐트제작은 일차적으로 방사선치료과의 필요 및 요청에 의해 결정되지만 환자구강의 특성에 따라 실용적 인 장치물을 배치 및 시공하기 위해서는 치과의 역할이 중요하며 치과보철의는 장치설계 및 제작을 통하여 방사 선 치료와 관련된 구강 합병증조절에 능동적으로 관여 할 수 있다. 본 보고의 볼러스삽입형의 경우 연구개암 부 위에 대한 조사효율 극대화, 설압형의 경우 방사선 조사 시 자세유지 및 인접 주요 조직기관(이하선) 보호에 관 한 협진이 방사선종양학과로부터 각각 요청되었다. 볼러 스함입형에 적용된 볼러스(bolus)는 피부 및 연조직과 거 의 유사한 밀도와 유효 핵전하를 가진 젤(gel) 형태의 조 직등가(tissue-equivalent) 물질로서 종양부위에 대한 방 사선의 균질한 조사를 유도하고 적정 치료선량을 표적의 특정 깊이까지 전달하는 역할을 한다. ${ }^{8}$ 조사 시 가장 많 은 방사선원 노출이 예상되는 피부점막의 표면부는 피하 $1-2 \mathrm{~cm}$ 보다 상대적으로 적은 양의 방사선이 흡수되는 데 ${ }^{9,10}$ skin-sparing effect ${ }^{11}$ 로 통칭되는 이 방사선역학 현 상은 연구개표면상에 걸친 종양을 치료하는데 약점으로 존재하게 된다. 따라서 $1 \mathrm{~cm}$ 두께의 젤을 표적부위에 덮 고 방사선을 조사하면 표피하방의 병변에 충분한 방사선 량을 전달할 수 있을 뿐만 아니라 불규칙한 연구개 종양 조직 표면이 이온화 빔 중심축에 대하여 조사각도가 수 직으로 보상되어 조사효율이 향상될 수 있다. 볼러스합 입형 스텐트는 볼러스를 담체하는 도구(carrier)인 동시 에 일종의 구강 보철물이므로 예비인상, 맞춤트레이, 변 연 및 후방경계 설정 그리고 유지장치 적용 등의 통상적 인 가철성 보철학의 원칙이 적용되었다. 연구개후방까지 확장된 스텐트의 후방경계는 착용 시 구토반사의 가능성 이 존재할 수 있으며 주인상 전 후방변연설정을 시행착 오적으로 시행하여 생리적 거부반사를 최대한 배제하였 다. 완성된 스텐트는 착용 후 모의방사선 치료를 시행하 여 실제 방사선치료과정을 위한 안정성 및 항상성을 확 인하였다. 설압형 마우스피스는 방사선원에 대하여 고정 되고 반복 가능한 환자 자세를 확보하기 위한 일종의 자 세유지(position maintaining device) 장치이다. 일반적 으로 입술, 혀, 뺨 등과 같은 가동성이 큰 조직기관의 움 직임을 최대한 제어하여 방사선 조사 간격마다의 오차 (interfraction setup error)를 감소시키는 목적으로 의뢰 된다. ${ }^{12,13}$ 설압형 마우스피스가 장착된 환자(Fig. $\left.4 \mathrm{C}\right)$ 는 교합제두께에 따라 일정한 개구량이 유지되고 동시에 하 방 풍융부는 혀를 압점하여 하악을 하방위치하게 한다. 이러한 형태의 마우스피스는 일정하고 고정된 개구상태 
를 유도하며 조사 시 상악 특히 이하선에 대한 방사선원 의 중심축을 멀어지게 하여 그 조사량을 감소시킬 수 있 다. ${ }^{14}$ 수직고경증가 및 설압 풍융부에 대한 피착용자의 생리적 반응 및 적응이 제작 시 고려되어야 하는데 극심 한 거부반응인 경우 장착이 원활치 않아 협진이 불가능 할 수 있으므로 모의치료 시 환자의 반응이나 편안함의 정도를 평가하는 것이 중요하다. 왁스림 시적 시 환자반 응은 일차적으로 중요하며 호흡기계 장애가 있는 환자의 경우 장치물 내 환기 구멍을 형성하여 방사선 치료 중 우 발적 합병증을 대비할 수 있다(Fig. 5). 구강암 치료에서 방사선 요법은 효과적으로 시행되고 있으나 조사 후 주 변 정상조직의 합병증 발생이 불가피할 수 있으며 술 후 보철수복의 진행을 고려할 경우 치과전문의에게도 큰 관 심요소가 될 수 있다. 때때로 두경부외과 의사 및 방사선 치료전문의는 치과전문의가 보철물을 사용하여 수행 할 수 있는 많은 일차적 도움을 완전히 인식하지 못할 수가 있다. 따라서 구강암에 대한 방사선 요법을 시작하기 전 에 다학적 소통 및 협진이 필요하며 이러한 조치는 치료 과정을 보다 원활하게하여 환자의 정신적 손상을 덜어주 는 동시에 술 후 구강회복에도 일조하게 한다.

\section{결론}

본 증례에서는 구강암 환자의 방사선치료 시 조사효율 극대화와 조사 주변조직의 보호를 위한 구강장치물로서 볼러스함입형과 설압형 마우스피스를 각각 제작 및 적용 하였다. 원활한 치료경과를 위한 다중 센터 전문가와의 충분한 협진이 방사선 치료 전 선행되어야 하며 이러한 다학제 작업은 방사선 치료 효율을 보다 원활하게 하고 향후 치과 치료를 포함한 치료 계획을 단순화할 수 있다.

\section{ORCID}

Ki Young Nam https://orcid.org/0000-0003-0481-0687

\section{References}

1. Lee VSK, Nguyen CT, Wu J. The Fabrication of an acrylic repositioning stent for use during intensity modulated radiation therapy: a feasibility study. J Prosthodont 2019;28:643-8.

2. Purdy JA. Dose to normal tissues outside the radia- tion therapy patient's treated volume: a review of different radiation therapy techniques. Health Phys 2008;95:666-76.

3. McCarthy D, Omer O, Nunn J, Cotter E. Oral health needs of the head and neck radiotherapy patients: 1. epidemiology, effects of radiotherapy and role of the GDP in diagnosis. Dent update 2005; 32:512-22.

4. Seo JG, Cho JH. Prosthetic rehabilitation for patient with hemi-maxillectomy: Obturator combined with a hybrid telescopic double crown using friction pin. J Dent Rehabil Appl Sci 2018;34:317-23.

5. Kaanders JH, Fleming TJ, Ang KK, Maor MH, Peters LJ. Devices valuable in head and neck radiotherapy. Int J Radiat Once Biol Phys 1992;23:63945.

6. Munshi A. Radiation oncology: Colors and hues. South Asian J Cancer 2014;3:16-7.

7. Aggarwal H, Kumar P. Radiation stents: minimizing radiation-induced complications. South Asian J Cancer 2014;3:185.

8. Wesson RA, Garden AS, Chambers MS. Fabrication of an unconventional bolus-type stent for a combined intraoral/extraoral defect treated with proton radiation therapy. J Prosthet Dent 2017;117: 563-5.

9. Mantri SS, Bhasin AS. Preventive Prosthodontics for Head and Neck Radiotherapy. J Clin Diagn Res 2010;4: 2958-62.

10. Brosky ME, Lee C, Barlett TS, Lo S. Fabrication of radiation bolus prosthesis for the maxillectomy patient. J Prosthet Dent 2000;83:119-21.

11. Kim SW, Shin HJ, Kay CS, Son SH. A customized bolus produced using a 3-dimensional printer for radiotherapy. PLoS One 2014;9:e110746.

12. Tryggestad E, Christian M, Ford E, Kut C, Le Y, Sanguineti G, Song DY, Kleinberg L. Inter- and intrafraction patient positioning uncertainties for intracranial radiotherapy: a study of four frameless, thermoplastic mask-based immobilization strategies using daily cone-beam CT. Int J Radiat Oncol Biol Phys 2011;80:281-90.

13. van Santvoort J, Wiggenraad R, Bos P. Positioning accuracy in stereotactic radiotherapy using a mask system with added vacuum mouth piece and stereo- 
scopic X-ray positioning. Int J Radiat Oncol Biol Phys 2008;72:261-7.

14. Ikawa H, Koto M, Ebner DK, Takagi R, Hayashi K, Tsuji H, Kamada T. A custom-made mouthpiece incorporating tongue depressors and elevators to reduce radiation-induced tongue mucositis during carbon-ion radiation therapy for head and neck cancer. Pract Radiat Oncol 2018;8:e27-31. 


\section{효율적 방사선요법을 위한 구강 방사선스텐트의 적용: 증례보고}

\section{남기영* 교수}

계명대학교 의과대학 치과학교실

구강방사선스텐트는 구강암의 방사선치료 시 종양조직에 적정 선량을 유도하거나 주변 정상 조직에 대한 불필요한 방 사선을 최소화하는 보조 장치이며 환자상황에 따라 개별적으로 적용되므로 효율적인 적용을 위한 관련 외과의, 방사선 치료전문의 그리고 치과전문의들간의 전략적인 협진이 필수적이다. 본 보고에서는 2종의 방사선스텐트(볼러스합입형, 설압형)를 다학제 협진하에 제작하였고 방사선치료 시 선택적으로 적용하여 그 효율성을 경험하였기에 증례와 함께 보 고하는 바이다.

(구강회복응용과학지 2020;36(4):282-8)

주요어: 다학제 연구; 구강암; 구강방사선스텐트; 방사선치료 